\title{
Analisis Penentuan Margin Pembiayaan Murabahah pada PT. Bank Syariah X Cabang Pontianak
}

\author{
Nur Fitriana Hamsyi* \\ Universitas Tanjungpura
}

\begin{abstract}
The purpose of this research is to find out how to determine the margin of murabahah financing, and components considered by Bank Syariah X Pontianak Branch. This is a qualitative descriptive research by investigating directly to the field in order to get more detail informations. Data collections were done by conducting observation, interview, documentation and literature study. From the research results, it can be concluded that the determination of murabahah margin in Bank Syariah X Branch Pontianak was using base lending rate approach where the components were among others the cost of fund, overhead cost, expected return, and risk premium. The margin set by the Syariah Bank at the beginning of the contract and should not be changed until the end of the contract and this distinguishes Islamic banks with conventional banks.
\end{abstract}

Keywords: margin, murabahah contract, sharia bank

\section{PENDAHULUAN}

Hadirnya perbankan syariah seakan-akan memberikan angin sejuk bagi perekonomian, sekaligus memberikan jalan keluar yang sangat tepat bagi umat islam. Terlebih di tengah kondisi kegalauan ekonomi yang disebabkan oleh krisis ekonomi dan moneter, dan adanya kerinduan sebagian masyarakat muslim akan adanya perekonomian syariah yang bersih dan bebas bunga. Salah satu faktor yang memicu terjadinya krisis ekonomi dan moneter tahun 1997 adalah ambruknya sistem perbankan. Yang menjadi permasalahan utamanya adalah inflasi yang dipicu oleh fluktuasi tingkat bunga sehingga menimbulkan adanya negative spread dan konsekuensinya bank harus menanggung rugi dalam kegiatan penghimpunan dan penyaluran dananya. Menurut Kasmir (2014) negative spread terjadi apabila suku bunga simpanan lebih besar dari suku bunga kredit. Krisis ini telah membawa dampak yang sangat buruk bagi lembaga perbankan Indonesia, karena beberapa bank tidak dapat bertahan dan akhirnya dilikuidasi. Hal ini menyebabkan kepercayaan masyarakat terhadap lembaga perbankan menurun.

Hal yang menarik dari krisis ini yaitu bank syariah seakan-akan tidak terpengaruh dengan adanya krisis tersebut. Faktor pendukung yang menyebabkan bank syariah lebih

\footnotetext{
* Korespondensi: Nur Fitriana Hamsyi, Fakultas Ekonomi dan Bisnis, Universitas Tanjungpura, Jalan Prof. Dr. H. Hadari Nawawi, Pontianak, Indonesia, Email: meeisya@yahoo.com.
} 
imun dibandingkan dengan bank konvensional karena bank syariah tidak menghadapai negative spread seperti yang dialami bank konvensional. Dalam bank syariah tidak dikenal istilah bunga dalam memberikan jasa kepada penyimpan maupun peminjam. Mengutamakan cara dan proses yang benar dalam meraih keuntungan merupakan aspek penting dalam kebijakan pengambilan keuntungan yang selaras dengan prinsip syariah. Untuk menghindari penerimaan dan pembayaran bunga (riba), maka perbankan syariah menempuh salah satu cara yaitu dengan memberikan pembiayaan berdasarkan jual beli dengan menggunakan akad murabahah.

Menurut pernyataan standar akuntansi keuangan (PSAK) 102, murabahah merupakan akad jual beli dengan menyatakan biaya perolehan barang ditambah keuntungan yang disepakati penjual dan pembeli. Dari pengertian tersebut dapat disimpulkan bahwa murabahah merupakan akad jual beli antara bank dengan nasabah dimana bank yang membiayai kebutuhan investasi nasabah membeli terlebih dahulu barang yang dibutuhkan nasabah, kemudian menjualnya kepada nasabah tersebut dengan menyebutkan harga perolehan ditambah keuntungan (margin) yang disepakati bersama. Margin ini biasanya dinyatakan sebagai persentase yang harus diterapkan pada semua biaya yang dikeluarkan oleh bank di dalam memenuhi murabahah.

Sistem pembiayaan di murabahah berbeda dengan sistem yang ada dalam skema kredit pada perbankan konvensional. Jika di konvensional sistem bunga kredit bisa fluktuatif sesuai dengan keadaan pasar, suku bunga, dan kondisi makro ekonomi, maka di bank syariah margin yang ditetapkan pada saat penandatanganan akad pembiayaan tidak boleh berubah meskipun terjadi inflasi, ataupun kenaikan tingkat suku bunga pasar. Keadaan ini berlaku hingga akhir pelunasan hutang nasabah kepada Bank. Karena itulah di bank syariah, tidak mengenal adanya review margin. Harga yang disepakati di awal akad transaksi pertukaran harus tetap, begitu juga kepemilikan tetap pada penjual sampai penyerahan dilakukan (El-Diwany, 2005).

Akad murabahah merupakan akad yang paling dominan disalurkan oleh bank syariah dibanding dengan akad pembiayaan lainnya. Dari sejak awal tahun 1984, di Pakistan, pembiayaan murabahah bisa mencapai sekitar delapan puluh tujuh persen (87\%) dari keseluruhan pembiayaan dalam investasi deposito profit and loss sharing (Lubis:2016). Banyak bank syariah begitu atraktif menawarkan produk pembiayaan komersial lewat pola jual beli (murabahah), salah satunya adalah PT. Bank Syariah X Cabang Pontianak. Dengan skema murabahah, Bank Syariah X membiayai kebutuhan nasabah dalam hal pengadaan barang konsumsi seperti rumah, kendaraan atau barang produktif. Dari penyaluran dana tersebut, bank memperoleh pendapatan berupa margin. Margin yang dimaksud di sini merupakan tingkat keuntungan yang diharapkan oleh bank syariah yang dinyatakan dalam bentuk nominal atau persentase tertentu (OJK:2016). Skim murabahah merupakan produk penyaluran dana yang digemari Bank Syariah X Cabang Pontianak, karena murabahah merupakan investasi jangka pendek yang karakternya profitable, mudah diterapkan, serta risk-factor yang ringan untuk 
diperhitungkan. Bukan hanya bank ini saja, masyarakat pun masih lebih akrab dengan murabahah dibandingkan dengan skim lainnya.

Dominannya transaksi murabahah akan membuat semua pihak gembira jika dilaksanakan sesuai dengan ketentuan dan prinsip-prinsip syariah yang berlaku. Di sisi lain, dominannya transaksi tersebut ternyata membawa implikasi yang sangat signifikan yaitu timbulnya berbagai persepsi yang masih belum tepat dari masyarakat yang belum paham sepenuhnya mengenai perbankan syariah, diantaranya mengenai keuntungan (margin) yang diambil oleh bank syariah. Penentuan margin di bank syariah merupakan bagian dari proses bisnis, mengingat dalam praktiknya bank syariah dilarang keras memungut bunga bank (Rejeki:2013). Namun, anggapan masyarakat pada umumnya adalah bahwa meminjam uang di bank syariah tidak akan dibebani bunga, dalam arti bank syariah tidak mengambil keuntungan dari penyaluran dana. Akibatnya ketika mengetahui bahwa bank syariah mengambil keuntungan, masih banyak orang yang kebingungan, seperti apa keuntungan yang diambil bank syariah itu. Jika bank syariah mengambil keuntungan nantinya sama saja dengan bunga.

Berawal dari hal tersebut, kesalahpahaman juga berlanjut mengenai besarnya margin murabahah yang diambil oleh bank syariah, sehingga muncul persepsi bahwa jika bank syariah mengambil keuntungan, harusnya lebih kecil dari bank pada umumnya. Dalam prakteknya, banyak yang masih mengatakan bahwa margin yang dibebankan bank syariah kepada nasabah relatif mahal atau bisa dikatakan masih tinggi. Bahkan dalam penentuan margin murabahah pun sering dikatakan mirip dengan penentuan suku bunga kreedit yang ada di bank konvensional.

Hal-hal seperti diatas membentuk paradigma masyarakat yang sangat tidak menguntungkan bagi pihak bank dimana sebagian masyarakat berpandangan bahwa bank syariah sama saja dengan bank konvensional, dan bank syariah sengaja menerapkan akad murabahah ini semata untuk mensiasati perolehan kuntungan atas pembiayaan yang disalurkan. Jika keadaan ini terus berlanjut tentu akan merusak citra perbankan syariah sebagai lembaga keuangan yang mengaku tunduk dan patuh mengikuti syariah. Padahal dalam perbankan syariah, margin dihitung berdasarkan komponen-komponen di mana data atau unsur yang dipergunakan dalam proses penentuannya ada yang berbeda dengan bank konvensional. Berdasarkan hal tersebut, maka diperlukan penelitian yang lebih mendalam untuk menganalisis penentuan margin pembiayaan murabahah pada PT. Bank Syariah X Cabang Pontianak.

\section{KAJIAN LITERATUR}

Salah satu skim fiqih yang paling populer digunakan oleh lembaga keuangan syariah adalah skim jual beli murabahah. Hal yang membedakan antara murabahah dengan penjualan yang biasa dikenal adalah dalam murabahah, penjual secara jelas memberi tahu harga pokok barang dan berapa besar keuntungan yang diinginkannya 
kepada pembeli (Nurhayati \& Wasilah, 2015). Transaksi murabahah ini lazim dilakukan Rasulullah SAW dan para sahabatnya. Menurut Antonio (2005) yang dimaksud dengan murabahah adalah jual beli barang pada harga asal di tambah dengan keuntungan yang disepakati. Karakteristik murabahah adalah penjual harus memberi tahu pembeli tentang harga produk yang ia beli dan menyatakan jumlah keuntungan yang ditambahkan pada biaya tersebut.

Adapun yang menjadi rukun transaksi murabahah menurut Yaya, Martawireja, dan Abdurahim (2014) meliputi adanya pihak yang bertransaksi dalam hal ini harus ada pembeli (nasabah) dan penjual (bank syariah), objek akad murabahah di mana di dalamnya terdapat barang dan harga, serta ijab dan kabul berupa pernyataan kehendak masing-masing pihak penjual dan pembeli. Untuk metode pengakuan keuntungan pembiayaan murabahah di lembaga keuangan syariah, Majelis Ulama Indonesia (MUI) telah mengeluarkan fatwa DSN No. 84/DSN-MUI/XII/2012 yang mengakui dua metode yaitu metode proporsional dan metode anuitas.

Berikut beberapa pendapat para ulama mazhab mengenai biaya-biaya yang dapat dibebankan pada harga jual barang tersebut: (1). Mazhab Maliki membebankan biaya biaya langsung yang terkait dengan transaksi jual beli itu dan biaya-biaya yang tidak langsung terkait dengan transaksi tersebut, namun memberi nilai tambah pada barang itu; (2). Mazhab Syafi'i membebankan biaya-biaya yang secara umum timbul dalam suatu transaksi jual beli kecuali biaya tenaga kerjanya sendiri karena komponen ini termasuk dalam keuntungannya. Begitu pula biaya-biaya yang tidak menambah nilai barang tidak boleh dimasukkan sebagai komponen biaya; (3). Mazhab Hanafi tidak membolehkan membebankan biaya-biaya yang memang semestinya dikerjakan oleh si penjual, namun membolehkan membebankan biaya-biaya yang secara umum timbul dalam suatu transaksi jual beli; 4). Mazhab Hambali membolehkan semua biaya langsung dan tidak langsung dibebankan pada harga jual selama biaya-biaya itu harus dibayarkan kepada pihak ketiga dan akan menambah nilai barang yang dijual. Landasan syariah murabahah yaitu terdapat di Al-Qur'an dalam surah An-Nisa ayat 29 sebagai berikut: "Hai orangorang yang beriman dan janganlah kamu makan harta sesamamu dengan jalan yang batil, kecuali dengan jalan perniagaan yang berlaku dengan suka sama suka diantara kamu ". Selain itu terdapat pula di surah Al-Baqarah ayat 275 yang berbunyi: "Dan Allah SWT telah menghalalkan jual beli dan mengharamkan riba".

Menurut Wiroso (2005), penentuan margin murabahah dapat dilakukan dengan dua pendekatan. Yaitu pendekatan pertama adalah pendekatan tukang sayur. Objek yang diperjual belikan dalam transaksi jual beli murabahah adalah komoditi. Sebagai penjual, bank syariah menawarkan harga jual berdasarkan harga pokok yang telah diinformasikan dengan jujur ditambah dengan keuntungan yang diharapkan dari nasabah selaku pembeli. Selanjutnya pembeli melakukan negosiasi atau tawar menawar sebesar harga pokok barang ditambah dengan keuntungan yang diinginkannya. Sebagai ilustrasi dapat kita ambil contoh tawar penawar yang dilakukan oleh tukang sayur. Bank yang bertindak 
sebagai penjual dan nasabah sebagai pembeli terlebih dahulu melakukan kesepakatan terhadap harga jual dan keuntungan dengan dilandasi keterbukaan., sehingga tidak terdapat pihak yang dirugikan.

Pendekatan kedua adalah lending rate bank konvensional (menggunakan persentase). Pendekatan ini dipergunakan oleh bank syariah dalam menentukan margin, namun data atau komponen-komponen yang digunakan dalam proses menghasilkan persentase keuntungan berbeda dengan bank konvensional. Data atau komponenkomponen tersebut antara lain: (a). Ekspektasi bagi hasil, menggunakan data rata-rata bagi hasil yang lalu, yang diberikan bank syariah kepada pemilik dana ditambah dengan kenaikan yang akan diharapkan dan lebih akurat apabila data ini merupakan gabungan rata-rata bagi hasil beberapa bank; (b). Overhead Cost, merupakan rata-rata beban overhead riil yang lalu, yang meliputi antara lain beban promosi, beban administrasi, beban personalia, dan beban ini tidak termasuk bagi hasil yang dibayar kepada nasabah; (c). Keuntungan, merupakan keuntungan normal dan layak diharapkan oleh bank syariah, dan keuntungan ini bukan spread seperti yang dilakukan bank konvensional; (d). Premi resiko, jika risk cost ini untuk menutup kegagalan nasabah yang tidak membayar, maka nasabah yang lancar harus dikembalikan (bukan sebagai pendapatan bank syariah).

Sedangkan Menurut Karim (2010), penetapan margin pembiayaan murabahah dapat dilakukan dengan mempertimbangkan beberapa komponen-komponen sebagai berikut: (1) Direct Competitor's Market Rate (DCMR), yaitu merupakan tingkat margin rata-rata beberapa bank syariah atau tingkat margin rata-rata perbankan syariah, atau ditetapkan dalam rapat asset and liability committee (ALCO); (2) Indirect Competitor's Market Rate (ICMR), yaitu tingkat rata-rata suku bunga perbankan konvensional; (3) Expected Competitive Return for Investors (ECRI), yaitu target bagi hasil kompetitif yang diharapkan dapat diberikan kepada dana pihak ketiga; (4) Acquiring cost, adalah biaya yang dikeluarkan oleh bank yang langsung terkait dengan upaya untuk memperoleh dana pihak ketiga; (5) Overhead cost, adalah biaya tidak langsung yang dikeluarkan oleh bank terkait dengan upaya untuk memperoleh dana pihak ketiga.

\section{METODA PENELITIAN}

Penelitian ini menggunakan metode deskriptif kualitatif dengan pendekatan studi kasus dimana obyek penelitiannya adalah PT. Bank Syariah X Cabang Pontianak. Ciri utama riset kualitatif prosedurnya bergantung pada data yang berbentuk teks dan gambar (Creswell, 2003). Penelitian deskriptif menurut Hanum (2014) merupakan metode penyusunan dan pengelompokkan data yang kemudian di interpretasikan sehingga memberikan gambaran riil mengenai objek penelitian. Dalam melakukan penelitian kualitatif, peneliti semestinya memahami permasalahan dari dalam konteks masalah yang diteliti (Sarwono, 2013). Oleh karena itu, peneliti disini lebih intens melakukan 
wawancara dan observasi langsung ke objek penelitian dalam hal ini adalah Bank Syariah X Cabang Pontianak.

Kecenderungan utama dari semua jenis studi kasus menurut Schramm dalam Yin (2012) adalah mencoba menjelaskan keputusan-keputusan terkait tentang mengapa studi tersebut dipilih, bagaimana mengimplementasikannya, dan apa hasilnya. Selain itu, Yin (2012) menjelaskan studi kasus lebih cocok digunakan apabila pokok pertanyaan suatu penelitian berkaitan dengan how atau why, bila peneliti hanya memiliki sedikit peluang untuk mengontrol peristiwa-peristiwa yang akan diselidiki, dan bilamana fokus penelitiannya terletak pada fenomena kontemporer di dalam konteks kehidupan nyata. Penelitian ini dimaksudkan untuk menganalisis dan menjelaskan bagaimana sebenarnya penentuan margin pembiayaan murabahah beserta komponen-komponennya dalam Bank Syariah X Cabang Pontianak.

Selain itu peneliti juga melakukan studi literatur dan dokumentasi dalam pengumpulan datanya. Sumber data yang digunakan adalah data primer yaitu data yang diperoleh langsung dari responden di objek penelitian untuk mendapatkan informasi yang lebih jelas dan spesifik. Metode analisis yang digunakan untuk menjawab permasalahan penelitian adalah dengan jalan memaknai data yang diperoleh di lapangan dan kemudian dibandingkan dengan teori yang ada.

\section{HASIL PENELITIAN DAN PEMBAHASAN}

Bank syariah menerapkan margin terhadap produk-produk pembiayaan yang berbasis natural certainty contracts (NCC), yakni akad bisnis yang memberikan kepastian pembayaran, baik dari segi jumlah (amount) maupun waktu (timing), salah satunya adalah pembiayaan murabahah. Dalam transaksi jual beli murabahah, bank syariah sebagai penjual menawarkan harga jual berdasarkan harga pokok yang telah diberitahukan dengan jujur ditambah dengan keuntungan yang diharapkan dari nasabah yang bertindak sebagai pembeli.

Margin yang terdapat pada pembiayaan murabahah ditentukan berdasarkan rekomendasi dan saran dari hasil rapat Tim ALCO. Artinya nilai margin dari hasil referensi ini menjadi standar acuan minimal untuk penetapan margin murabahah di Bank Syariah X Cabang Pontianak. Khusus murabahah ini, ceiling price juga kadang menjadi acuan utama dalam penentuan margin. Berikut adalah hasil wawancara dengan Bapak A selaku management trainee di Bank Syariah X Cabang Pontianak:

"Dalam prakteknya justru ceiling price yang jadi acuan utama. Ceiling price ini adalah tingkat margin "tertinggi" yang diberlakukan untuk murabahah".

Penentuan margin murabahah menggunakan acuan base lending rate, seperti yang diilustrasikan dibawah ini. Bapak AA membutuhkan dana untuk membeli sebuah mobil yang akan digunakan untuk memperlancar usahanya. Untuk itu, Bapak AA mengajukan pembiayaan murabahah ke Bank Syariah X Cabang Pontianak. Dana yang dibutuhkan 
untuk membeli sebuah mobil tersebut adalah sebesar Rp 150.000.000, dan margin yang dibebankan kepada nasabah sebesar Rp 22.500 .000 (setara dengan 15\%). Maka rincian komponen dalam penentuan margin $15 \%$ adalah sebagai berikut :

\begin{tabular}{ll} 
Ekspektasi bagi hasil & $=8 \%$ \\
Overhead cost & $=2,5 \%$ \\
Keuntungan yang diharapkan & $=2 \%$ \\
Premi resiko & $=\underline{2,5 \%}$ \\
\multicolumn{1}{c}{ Margin } & $=15 \%$
\end{tabular}

Jika dilihat dari komponen-komponen margin diatas, maka yang merupakan komponen base lending rate (BLR) adalah: ekspektasi bagi hasil, biaya overhead (overhead cost), dan keuntungan yang diharapkan. Setelah mendapatkan nilai BLR, kemudian ditambah dengan premi resiko sehingga menghasilkan margin. Dalam hal premi resiko menurut teori Wiroso (2005), jika premi resiko ini untuk menutup kegagalan nasabah yang tidak membayar, maka nasabah yang lancar harus dikembalikan (bukan sebagai pendapatan bank syariah). Hal ini berbeda dengan apa yang diterapkan di Bank Syariah X Cabang Pontianak dimana jika nasabah lancar, maka premi resiko dari nasabah tersebut tidak dikembalikan tetapi bisa saja menjadi pendapatan bank syariah atau digunakan untuk menutup kegagalan nasabah lain.

Jika dibandingkan kondisi riil dengan teori (konsep) menurut Wiroso, hal ini kurang sesuai, dimana nasabah yang lancar harus ikut menanggung kegagalan nasabah lain yang mengalami kemacetan dalam membayar. Memang dalam bank syariah jika aktiva produktif bermasalah yang menanggung resiko tidak semata-mata bank syariah sendiri, tetapi juga nasabah. Karena aktiva produktif yang buruk akan memberi dampak bagi hasil yang diterima nasabah juga kecil seiring dengan pendapatan yang diterima turun. Tetapi sebaiknya tidak semua premi resiko dari nasabah lancar tersebut, digunakan untuk menutup kegagalan nasabah lain. Walau bagaimanapun, setiap nasabah sudah diprediksi masing-masing premi resikonya dan bank syariah hendaknya harus dapat menghitung premi resiko yang dikenakan untuk masing-masing debitur dengan cermat. Jika ada nasabah yang ternyata macet dalam pembayaran, bank masih bisa mengatasi dari premi resiko nasabah yang macet tersebut. Seandainya kegagalan macet tersebut besar, maka bank bisa menutupinya dengan sebagian dari premi resiko nasabah yang lancar. Jadi, tidak harus semua porsi nasabah lancar ini harus digunakan untuk menutupi kegagalan nasabah lain. Oleh karena itu, jika nasabah tersebut lancar membayar, sebagian premi resikonya bisa dikembalikan dalam bentuk diskon hingga sehingga besarnya margin yang dibebankan kepada nasabah tersebut juga bisa menjadi berkurang.

Di bank konvensional, porsi ini diakui sebagai pendapatan bank apapun kategori nasabahnya. Bank syariah sendiri semestinya bisa menghitung premi resiko yang dikenakan untuk masing-masing debitur dengan cermat. Besarnya premi resiko (risk 
premium) yang ditentukan Bank Syariah X Cabang Pontianak berbeda-beda nilainya, tergantung pada jenis pembiayaan. Dalam hasil wawancara, Bapak A mengatakan:

"Untuk beberapa produk, seperti konsumer dan mikro, risk premium merupakan sesuatu yang given (standarized) dan bersifat top up. Faktor apapun hampir tidak mungkin mengubah price di dua sektor itu".

Banyak faktor yang dipertimbangkan dalam penentuan risk premium, diantaranya adalah rating perusahaan, agunan, jenis sektor usaha, jenis pembiayaan yang akan diberikan, keyakinan akan terjadinya resiko kredit, volume kredit yang diberikan, hubungan baik antara bank dan nasabah dalam arti historical records nasabah yang bersangkutan cukup baik dan memberikan keuntungan bagi bank serta kondisi persaingan yang ada. Semakin tinggi rating yang dimiliki perusahaan, semakin rendah juga tingkat resikonya. Sebagai pihak yang menyalurkan dana, Bank Syariah X Cabang Pontianak pastinya sangat berhati-hati dalam menilai resiko, karena Bank tentu tidak mau mengambil resiko yang terlalu besar. Untuk itu bank benar-benar akan mempelajari proposal permohonan pembiayaan yang diajukan oleh calon nasabah. Semakin tinggi return yang akan didapatkan semakin besar resiko yang akan terjadi. Begitu juga dengan jangka waktu pembiayaan, jatuh tempo pembiayaan yang lebih panjang cenderung memiliki resiko yang lebih tinggi pula yaitu ketidakpastian terhadap pelunasan yang terdiri dari pembayaran pokok dan margin. Sehingga bank harus mempertimbangkan hal tersebut.

Dalam praktik yang dijalankan oleh Bank Syariah X Cabang Pontianak yang menerapkan perhitungan base lending rate, walaupun telah diperoleh perhitungan terhadap angka yang akan dipergunakan sebagai dasar dalam menentukan besarnya keuntungan, namun dalam penerapannya bank syariah disini tetap memperhatikan harga pasar. Pada umumnya, untuk mengantisipasi akan kenaikan harga pasar setelah akad berlangsung, terkadang margin yang ditetapkan diawal akad lebih tinggi dari harga pasar. Jadi, margin sebesar $15 \%$ tersebut bisa saja dinaikkan, misalnya sebesar $1 \%$ sehingga total margin yang dibebankan kepada nasabah menjadi sebesar $16 \%$.

Akan tetapi, harga pasar disini hanya digunakan sebagai rujukan untuk perbandingan dalam awal akad penentuan margin saja, bukan sebagai patokan untuk proses seterusya. Di sini bank syariah dituntut untuk berhati-hati, artinya jika terjadi kenaikan harga pasar pada saat akad telah berlangsung, maka margin yang telah ditetapkan diawal tadi tidak boleh berubah. Jika berubah, maka akad tersebut menjadi batal dan inilah yang tidak sejalan dengan prinsip syariah. Sebelum memutuskan besarnya margin yang akan diberikan, Bank Syariah X Cabang Pontianak harus melihat dulu jenis pembiayaan yang diberikan, apakah termasuk pembiayaan produktif (modal kerja/investasi) atau pembiayaan komsumtif. Karena tingkat margin yang dikenakan kepada nasabah berbeda antara jenis pembiayaan yang satu dengan yang lain. Begitu juga premi resiko masing-masing jenis usaha dan pembiayaan memiliki persentase berbeda tergantung pada beberapa faktor, seperti kondisi usaha dan rating perusahaan. 
Penentuan keuntungan (margin) murabahah dengan pendekatan base lending rate seperti bank konvensional bukanlah hal yang salah, namun yang perlu dicermati di sini adalah data-data yang dipergunakan di dalam komponen untuk menentukan base lending rate tersebut. Jadi yang perlu dicermati di sini bukan hasil akhir yang menghasilkan persentase, namun proses untuk menghasilkan persentase tersebut. Komponen dalam penentuan base lending rate yang ada di Bank Syariah X Cabang Pontianak sesuai dengan teori yang terdapat di Wiroso (2005) di mana data yang dipergunakan atau unsur-unsur dari komponen tersebut terdiri dari empat hal.

Pertama, cost of money (COM) yang merupakan seluruh biaya yang dikeluarkan untuk menghasilkan produk pinjaman, terdiri dari cost of loanable fund dan overhead cost. Seluruh biaya dana yang dikeluarkan oleh bank untuk mendapatkan dana inilah dinamakan cost of loanable fund (COLF). Komponen yang terkandung dalam COLF di Bank Syariah X Cabang Pontianak yaitu cost of fund (COF). Bapak A menjelaskan :

"Cost of fund, intinya itu biaya yang dibayar bank kepada pihak pemilik dana. Karena sebagian besar dana bank berasal dari simpanan (giro, tabungan, dan deposito), komponen perhitungannya dari sana saja."

COF dalam lending rate bank konvensional adalah total biaya yang dikeluarkan oleh bank untuk memperoleh dana simpanan baik dalam bentuk giro, tabungan maupun deposito sebelum cadangan likuiditas wajib ditentukan oleh pemerintah, seperti biaya bunga dana, biaya promosi dan overhead cost. Karena imbalan yang diberikan bank konvensional kepada pemilik dana berupa bunga yang besarnya telah ditetapkan di awal, maka semakin besar bunga yang dibebankan terhadap bunga simpanan maka semakin besar pula biaya danannya demikian sebaliknya. Berbeda dengan bank konvensional, bank syariah tidak pernah membayarkan imbalan dalam jumlah yang pasti kepada pemilik dana. Imbalan yang diberikan merupakan porsi hasil usaha (pendapatan) yang besarnya sangat tegantung dari hasil kinerja bank syariah dalam mengelola dan menyalurkan dana yang secara riil diterima oleh bank syariah. Unsur COF dalam penentuan lending rate yang ada di Bank Syariah X Cabang Pontianak adalah ekspektasi bagi hasil (expected return) sebagaimana yang diungkapkan Bapak A dibawah ini :

"Di Bank Syariah X Cabang Pontianak, kami kelompokkan cost of fund menjadi satu dalam perhitungan expected return atas dana pihak ketiga (simpanan). Karena menggunakan sistem bagi hasil, expected return ini berubah-ubah setiap bulannya."

Penentuan ekspektasi bagi hasil (expected return) inilah yang mesti dilakukan Bank Syariah X Cabang Pontianak untuk menentukan margin murabahah, dimana datanya diperoleh dari rata-rata bagi hasil yang telah diberikan Bank Syariah X Cabang Pontianak kepada nasabah yang bisa diambil dari data-data riil yang lalu atau data dari beberapa bank syariah, kemudian ditambah dengan estimasi tambahan yang akan diharapkan. Yang diperhitungkan dalam ekspektasi bagi hasil ini hanyalah dana yang 
dihimpun dengan prinsip murabahah saja dan nilainya bisa berubah-ubah setiap bulannya tergantung dari hasil kinerja Bank Syariah X Cabang Pontianak.

Komponen kedua dalam perhitungan lending rate Bank Syariah X Cabang Pontianak adalah overhead cost. Di bank konvensional overhead cost menjadi bagian dari unsur cost of fund, karena biaya ini berkaitan dengan semua biaya yang dikeluarkan bank untuk memperoleh penghimpunan dana. Sebaliknya, di Bank Syariah X Cabang Pontianak, biaya promosi dan overhead cost bukan menjadi bagian dari unsur COF. Biaya promosi menjadi bagian dari overhead cost, sedangkan overhead cost merupakan komponen tersendiri diluar COF yang menjadi bagian dari lending rate dalam perhitungan margin. Biaya overhead dihitung dari biaya overhead yang riil dikeluarkan Bank Syariah X Cabang Pontianak seperti biaya tenaga kerja, administrasi dan umum (general and administrative) dan biaya lainnya. Biaya general and administrative (GA) disini adalah biaya administrasi dan umum terkait kantor, bukan biaya administrasi untuk pembiayaan yang telah dikenakan di awal. Bapak A menjelaskan :

"Di internal kami, penentuan overhead cost masih bersifat budgeted portion (porsi yang direncanakan). Idealnya, diambil dari past performance, kemudian dibuatkan trend dari komponen-komponen overhad cost, seperti biaya tenaga kerja, biaya GA, biaya promosi, dan beberapa biaya lain. GA disini lebih ke GA kantor."

Komponen yang terakhir adalah spread atau tingkat keuntungan yang diharapkan (expected return). Dalam bank konvensional spread merupakan keuntungan sebagai akibat dari selisih bunga yang dibayar kepada deposan dan bunga yang diterima dari debitur. Sedangkan di bank syariah tidak mengenal istilah tersebut. Penentuan keuntungan di Bank Syariah X Cabang Pontianak merupakan keuntungan yang memang benar-benar diharapkan oleh bank syariah itu sendiri yang berdasarkan pada perhitungan return on asset (ROA).

Sedangkan pajak bukan merupakan bagian dari komponen yang dijadikan pertimbangan Bank Syariah X Cabang Pontianak dalam penentuan base lending rate. Pajak perusahaan ditanggung oleh bank syariah sendiri, sebagaimana yang dikemukakan oleh Bapak A sebagai berikut :

"Sudah ketentuan perpajakan, transaksi murabahah di Bank Syariah tidak dikenakan pajak. Dulu memang sempat di wacana, akhirnya pihak bank syariah jelaskan detail tentang murabahah. Jika dikenakan akan jadi pajak berganda."

Lebih lanjut Bapak A juga menjelaskan :

"Karena murabahah produk bank, dia tidak dikenakan pajak pertambahan nilai (PPN) atas tambahan margin bank. Untuk PPN atas barang berhenti sampai perhitungan harga beli kami saja. Jadi komponen murabahahnya demikian, harga beli ditambah margin sehingga didapatlah harga jual."

Perihal pajak di pembiayaan murabahah ini sebenarnya pernah menjadi permasalahan dalam bank syariah. Karena dirjen pajak (fiskus) mengingingkan margin 
murabahah bank dikenakan PPN, dan bank dikenakan PPh kembali atas keuntungan yang diperoleh. Namun bank syariah sudah menjelaskan bahwa murabahah adalah produk bank sehingga tidak dikenakan pajak lagi atas tambahan margin bank. Jika dikenakan pajak lagi akan menjadi pajak berganda (double taxation).

Dengan demikian komponen-komponen utama yang terkandung dalam base lending rate (BLR) dalam Bank Syariah X Cabang Pontianak hanya terdiri dari 3 saja yaitu : cost of fund, overhead cost dan expected return. Setelah BLR ditetapkan nilainya, kemudian ditambah dengan maximized risk premium dan didapatlah nilai margin pembiayaan murabahah.

\section{SIMPULAN}

Dalam praktiknya, penentuan margin pembiayaan murabahah di Bank Syariah X Cabang Pontianak menggunakan pendekatan base lending rate yang dinyatakan dalam bentuk persentase. Namun, data yang dipergunakan atau unsur-unsur dari komponen base lending rate (BLR) Bank Syariah X Cabang Pontianak berbeda dengan base lending rate yang dilakukan oleh bank konvensional. Adapun komponen-komponen utama yang terkandung pada BLR dalam penentuan margin murabahah di Bank Syariah $\mathrm{X}$ Cabang Pontianak adalah: cost of fund, overhead cost, dan keuntungan yang diharapkan (expected return). Untuk menghasilkan margin, nilai BLR ini akan ditambah dengan premi resiko yang sudah ditentukan nilainya. Margin murabahah ini ditentukan berdasarkan keputusan dari hasil rapat tim ALCO (Assets and Liability Committe) bank syariah, sehingga menjadi rate margin minimal yang diterapkan oleh Bank Syariah X di seluruh Indonesia.

Perihal pembebanan premi resiko, jika dicermati dari apa yang diterapkan pada Bank Syariah X Cabang Pontianak, maka masih ada kekurang sesuaian dengan teori (konsep) menurut Wiroso (2005), dimana dikatakan jika premi resiko ini untuk menutup kegagalan nasabah yang tidak membayar, maka nasabah yang lancar preminya harus atau sebagian dikembalikan (bukan sebagai pendapatan bank syariah). Namun, bank masih jarang mengembalikan porsi ini pada nasabah yang lancar. Dalam praktek yang dijalankan oleh bank syariah, walaupun telah diperoleh perhitungan terhadap angka yang akan dipergunakan sebagai dasar menentukan besarnya keuntungan, namun dalam penerapannya bank syariah tetap memperhatikan harga pasar. Sehingga terkadang pengenaan margin di awal akad, lebih tinggi dari harga pasar untuk mengantisipasi adanya perubahan harga pasar nantinya. Karena dalam bank syariah tidak mengenal istilah review margin jika akad telah berlangsung. 


\section{DAFTAR PUSTAKA}

Al-Qur'an. (2015). Al-Qur'an dan Terjemahan. Departemen Agama RI. Bandung: CV. Diponegoro.

Antonio, M. S. (2005). Bank Syariah dari Teori ke Praktik. Jakarta: Gema Insani Press.

Creswell, J. W. (2003). Research Design : Qualitative, Quantitative and Mixed Methods Approaches. London: SAGE Publications.

El-Diwany, T. (2005). The Problem with Interest. Jakarta: Akbar Media Eka Sarana.

Hanum, Z. (2014). Analisis Penerapan Transaksi Murabahah pada PT. Bank Pembiayaan Rakyat (BPR) Syariah Gebu Prima Medan. Jurnal Ilmu Ekonomi dan Pembangunan. 14 (01).

Ikatan Akuntan Indonesia. (2016). Standar Akuntansi Keuangan Syariah. Jakarta: DSAK-IAI.

Karim, A. (2010). Bank Islam: Analisis Fiqih dan Keuangan. Jakarta: PT. Raja Grafindo Persada.

Kasmir. (2014). Bank dan Lembaga Keuangan Lainnya. Jakarta: PT. Raja Grafindo Persada.

Lubis, A. (2016). Aplikasi Murabahah dalam Perbankan Syariah. FITRAH. 02 (2). 181-202.

Majelas Ulama Indonesia. (2012). Metode Pengakuan Keuntungan Al-Tamwil Bi-AlMurabahah (Pembiayaan Murabahah) di Lembaga Keuangan Syariah. Fatwa Dewan Syariah Nasional No. 84/DSN-MUI/XII/2012. Jakarta: DSN-MUI.

Nurhayati, S., \& Wasilah. (2016). Akuntansi Syariah di Indonesia. Jakarta: Salemba Empat.

Otoritas Jasa Keuangan. (2016). Standar Produk Perbankan Syariah Murabahah. Dapartemen Perbankan Syariah: OJK.

Rejeki, F.Y.S. (2013). Akad Pembiayaan Murabahah dan Praktiknya pada PT. Bank Syariah Mandiri Cabang Manado. Lex Privatum. 01. (02). 19-31.

Sarwono, J. (2013). Strategi Melakukan Riset. Yogyakarta: CV. ANDI.

Wiroso. (2005). Jual Beli Murabahah. Yogyakarta: UII Press.

Yaya, R., Martawireja, A.R, \& Abdurahim, A. (2014). Akuntansi Perbankan Syariah. Jakarta: Salemba Empat.

Yin, R.K. (2012). Studi Kasus Desain \& Metode. Jakarta: PT. RajaGrafindo Persada. 